\title{
Gesturing towards radical futurity in education for alternative futures
}

\author{
Sarah Amsler ${ }^{1}[$
}

Received: 1 September 2018 / Accepted: 27 February 2019 / Published online: 13 March 2019

(c) The Author(s) 2019

\begin{abstract}
This comment paper reflects on the challenges and possibilities of interdisciplinary, translocal efforts to create pedagogies that invite people to grapple with the foundations of global social and ecological injustice, and the difficulties of transforming them. It begins from a proposition that there is a 'blind spot' in analyses that uphold the sustainability of globalized capitalism and its interlocking systems of racialized and gendered oppression as a viable form of life. It considers how an 'alternative thinking of alternatives' is being practiced in learning spaces where future-making practices are being developed that recognize the harmful effects of this blind spot. It emphasizes the importance of learning from both the successes and failures of these efforts. In particular, it identifies common circularities that emerge in alternative spaces that seek to transcend complicity in harm and gloss over the difficulties of transformative change. It describes how one collectively approaches these difficulties by starting from acknowledging the irreducible complexity and complicity of efforts to 'gesture' towards future-making practice for viable ecological futures.
\end{abstract}

Keywords Complicity $\cdot$ Decolonization $\cdot$ Future-making practice $\cdot$ Learning $\cdot$ Modernity

\section{Introduction}

Strengthening knowledge about and sensitivity towards the violence of climate change in order to slow its acceleration and reduce or reverse its effects is a guiding principle of education for ecological justice today. This principle is rooted in a belief that organized learning is a tool for social improvement and that 'human beings are malleable, body and mind, down to their very instinctual structure' (Marcuse 1992). Yet the assumption that people can become 'conscious of their inconclusiveness' (Freire 2016) does not necessarily mean we are open to the kinds of ontological changes - in other words, changes to the structure of our very modes of existence-that are needed if possibilities for radically different futures are to emerge, futures, that is, in which no being is threatened with extermination by the

Handled by: Anne-Katrin Holfelder, Institute for Advanced Sustainability Studies eV, Germany.

Sarah Amsler

sarah.amsler@nottingham.ac.uk

1 School of Education, University of Nottingham, Jubilee Campus, Nottingham NG8 1BB, UK instrumentalization of life for another's power and profit, and in which future-making practices are oriented not towards minimizing risks to this power but towards creating and defending life in its diversity. Such learning aims not to help us sustain or become resilient within harmful environments that are conceived as inevitable, but to generate possibilities for fundamentally other ways of organizing life even before conditions of possibility for their intelligibility or desirability emerge. Such learning diverges from approaches to social and ecological justice education that focuses on how to 'live well, without compromising the planet's continuing ability to enable us all to live well' (Green 2015), or to empower 'everyone to make informed decisions for environmental integrity, economic viability and a just society for present and future generations, while respecting cultural diversity' (UNESCO 2018). It rather invites us to 'travel together differently' to experiment with thinking and being in notyet known ways as part of a planet fighting for survival in anticipation of its own death (Andreotti et al. 2018), and to practice becoming 'otherwise' by embracing 'forms of life that are at odds with dominant, and dominating, modes of being' (Povinelli 2011, 2012).

This paper reflects on two translocal efforts to develop this kind of learning practice (with 'translocal' referring to 
activities and processes that take place in multiple localities and sometimes at different scales, for example, in a local community, a regional artistic collective and the everyday practices of an international organization). It begins from a proposition that there is a 'blind spot' in analyses of social and ecological justice that uphold the sustainability of globalized capitalism and its interlocking systems of racialized and gendered oppression as a viable form of life. This is because, as is increasingly recognized by transdisciplinary scholars and activists (Steelman et al. 2018), attempts to reduce the injustices of this system while maintaining its overall operation do not challenge the underlying logics of social organization that are both a major source of social and ecological suffering and the conditions of possibility for the system itself. These logics are rooted in a number of beliefs. One is that human beings are separate from nature and other living beings, and that we can instrumentalize both for our own profit and survival. The second is that there are natural hierarchies and divisions, particularly of race and gender, among human beings at local and global levels. The third is that understanding the world through rational, conceptual, linguistic and scientific (or 'logocentric') methods is all that is needed to imagine, design and implement policies that promote well-being and prosperity (Andreotti et al. 2018; Dorling 2010; Santos 2017). The systems of economic, political and cultural power that emerge from this logiccolonial capitalism including ecological exploitation and expropriation; patriarchy, white supremacy and the nation state; and the dominance of local European epistemologies and ontologies over other ways of knowing and being have become naturalized realities in everyday life and global governance, and are often regarded as the only possible ways of organizing collective life today.

Believing that this politically constructed reality is an inevitable context for contemporary struggles to realize social and ecological justice offers a seductive 'ontological security' that bestows legitimacy and value upon transformative practices (Stein et al. 2017; Shahjahan and Wagner 2018). In other words, if we assume that this is the only way the world is and the only way it realistically can be, it makes sense and feels good to find ways of modifying or adapting to it. However, this belief also creates ontological 'absences' that prevent us from learning from other logics of social organization, accessing deeper understandings of how 'progressive' educational practices can reproduce the very sources of social and ecological harm they seek to heal, and obscure our own complicities in this process (Walton 2018; Weber 2017). For example, maintaining a 'humancentred paradigm of absolute knowability and certainty' (Shahjahan and Wagner 2018) may increase learners' sense of 'efficacy' in making changes in their world, but deprives them of opportunities to be taught by non-human entities and phenomena that cannot be known in this paradigm — as recognized by quantum field physicists (Barad 2015), sustainability scientists (Williams 2013) and Indigenous peoples (Ahenakew et al. 2014) —or to develop the wilful endurance needed to participate in processes of emergent learning that do not conform to the temporalities of either capitalist productivity or activist urgency (Povinelli 2011). Similarly, by framing the causes of ecological problems either as technical deficiencies that can be solved with better tools and strategies (Amsler 2009) or as 'a lack of knowledge and social consensus that can be addressed with more data, and more effective communication' (Andreotti et al. 2018), learners may not understand how to engage with the material, relational and spiritual injuries of modern power that cannot be healed with instrumental knowledge or action. And by seeking to make people and all nature 'resilient' to the vagaries and violence of capitalism, we deny ourselves opportunities to disinvest from, rather than further invest in, social structures that may be 'dying and need to be "hospiced" rather than preserved, even when their alternatives are not yet known (Shahjahan et al. 2017). Ultimately, educating for social and ecological change within this 'contracted experience of reality' (Williams 2013) blocks our access routes to the diverse ways of knowing, being and making futures-some of which have long been practiced in the margins and cracks of the dominant system, and others which exist in states of emergence- that expand our imagination of how collective life is and can be organized (Santos 2017).

Marcuse argued decades ago 'that an alternative quality of life is possible has been proven' (Marcuse 1992); an observation echoed recently in sociologist Boaventura de Sousa Santos' observation that while alternatives to capitalist development abound, we lack 'an alternative thinking of alternatives' themselves (Santos 2016); in particular, one that invites unanticipated learning from divergent knowledges and does not rely on the hope for 'redemption'. Yet he has also argued that people of the global North have 'lost the capacity to learn from the experiences of the world' (Santos 2016), and that although 'many non-Western (indigenous, rural, etc.) populations of the world conceive of the community and the relationship with nature, knowledge, historical experience, memory, time, and space as configuring ways of life that cannot be reduced to Eurocentric conceptions and cultures', these options are either romanticized as 'alternatives' or inaccessible within Eurocentric realities because they are considered 'other' and therefore irrelevant, or not scientifically robust (Santos et al. 2007). Yet even at the highest levels of global educational governance, it has been recognized that the knowledge and sensibilities of European modernity cannot alone address contemporary problems of global social and ecological injustice, in part because they are implicated in its cause (UNESCO 2005). What pedagogical practices might reopen these connections, and through 
them possibilities for contributing to social and ecological justice otherwise, in ways that do not simply transfer colonizing modes of hoping (i.e. those that anticipate salvation) onto the radical otherwise?

One suggestion is that shifting the geography of learning - organizing it outside hegemonic institutions and their regimes of recognition, worth and value - can create possibilities for inhabiting other places 'in geographical, emotional and theoretical terms from where [we] speak' (Giraldo 2016). More than a decade ago, Raymundo Sánchez Barraza, coordinator of the Centro Indigena de Capacitación Integral in Chiapas, Mexico, argued that 'what we see is that this system has come to an end like others have. Hope, therefore, belongs to the resistance, but it is the hope that something else is possible...' (Barraza 2005). This 'something else' is the possibility of dignified and holistic life that is not destroyed by the 'model of profits, marketing, exploitation, greed, control [and] contempt for the different'. In an effort to foster this 'something else', people have sought to create educational spaces that exist not to ensure the continuous development of destructive social systems, but to cultivate non-violent forms of life now regardless of 'whether the world is going to survive' (Barraza 2005). For those who have been socialized within mainstream institutions, however, even in these alternative spaces we often bring with colonial habits of being that block the potential knowing, being, relating and desiring differently. Rather than being models of 'solutions', these spaces should therefore be considered learning experiments that can offer space to create something different and opportunities to learn from both the successes and failures of these efforts.

Shifts in the geography of learning for alternative social and ecological alternatives can be observed globally in the emergence and convergence ('networking') of learning projects in which alternative future-making practices are being explored. These include many rural and urban programmes organized around indigenous knowledges, which are beyond the scope of this paper to discuss (EarthCARE Network 2018). They also include collectives of practitioners from diverse contexts such as antiracist and transactivism, the arts, community organizing, cooperative education, environmental education, healing justice, learning amidst highintensity poverty and political struggle, and land-based and place-based pedagogies. One example, the global 'Ecoversities Alliance', grew from pollination between projects where 'knowledge and learning are not being pursued for profit or training for the market' but 'nurturing wisdom for people's potential to transform themselves, their communities and the places they live in' (Enlivened Learning 2018; Ecoversities 2018). Now in its third year, this expanding network attracts people who are active not only in "critiquing our broken education systems but also in cultivating new stories, practices, possibilities, and emergences that reconnect and regenerate local ecological and cultural ecosystems' (Teamey and Mandel 2018). They advance this work by organizing gatherings in which to share knowledge and practices that stretch or diversify existing frames of reference (ways of knowing, relating and being), deepen reflection on the affordances and limitations of their paradigms, and develop new vocabularies that decentre dominant grammars of knowing and being.

Much important learning has already emerged from the creation of these transnational meetings and conversations to reimagine education for the future. One important lesson is that it is difficult to enact other ways of being and opening up radically different futures in ways that do not reproduce at least some of the same patterns that they seek to transcend (Teamey and Mandel 2018). Indeed, the will to transcend these patterns can sometimes create a circularity as the desire to arrive immediately at a changed future may result in the glossing over of deeper enduring problems. For instance, efforts to share knowledges from across contexts characterized by historically uneven power relations can reproduce enduring practices of appropriation. This is because having an intellectual critique of harmful colonial patterns does not automatically lead to deeper changes in desire. Intellectually desiring a different future does not necessarily translate into wanting to relinquish the securities of systems that maintain the status quo, particularly when these promise stability, affirmation and rewards for 'making change'. Yet desiring quick resolutions and shortcuts to an 'elsewhere' that does not require giving up these promises can suppress difficult but necessary conversations about our own dependency on and complicity with the very systems we seek to transform (Jefferess 2012).

Another translocal network working to develop ontologically focused social and ecological justice pedagogies, 'Gesturing Towards Decolonial Futures' (hereafter GTDF), seeks not only to address this irreducible complexity and complicity but also to centre it in their practice. This 'collective of artists, educators, artist-educators and scholars' from across the world meets virtually and in body to experiment with art, social cartography and pedagogies which 'enable ways of doing, thinking, and being that are viable but unimaginable within the modern-colonial imaginary' (Gesturing Towards Decolonial Futures 2018a). This is important because this imaginary perpetuates what Maria Lugones, following Anibal Quijano, calls the 'coloniality of power' (Lugones 2010): not just the classification of people into hierarchical groups but 'also the process of active reduction of people, the dehumanization that fits them for the classification, the process of subjectification, the attempt to turn the colonized into less than human beings', and to render non-hegemonic ways ofknowing and being as non-existent, or 'not existing in any relevant or comprehensible way of being' and therefore 'beyond the realm of what the accepted conception of inclusion considers to be its other' and worthy 
of consideration (Santos 2017). The GTDF project proposes that this powerful paradigm is anchored not only in what we and how we think but also in our bodies (from reflexes to the ways we inhabit space); psyches; identities; relationships of livelihood and social reproduction; sense of well-being, worth and purpose; and modalities (how we experience reality and possibility), and that 'unlearning' harmful ways of being requires relearning in these domains.

Like other educational experiments, both the failures and successes of GTDF offer learning for others who seek to imagine education differently. The collective sees its failures as a part of the process of 'hospicing' an old world and midwifing a new one. One of its orienting concerns is therefore to start and stay with complicity in the system we critique, and to remain self-reflexively attentive to the tendency to reproduce harmful systemic patterns. Rather than seek a position of absolution, purity or innocence, as Shotwell (2016) suggests, we 'start from an assumption that everyone is implicated in situations we (at least in some way) repudiate. We are compromised and we have made compromises, and this will continue to be the way we craft the worlds to come, whatever they might turn out to be' (p. 5). This approach asks what responsibility for the future looks like when starting from the impossibility of transcending our implication in past, present and future harm. It requires an orientation to the future that is premised on humility and generosity rather than heroism and leadership, and suggests that the former are not intellectual choices but practices of engaging with the world that result from affective shifts which enable us to divest from desires for future control, accumulation, authority and entitlement.

One pedagogical method used to facilitate this practice is the creation and mobilization of visual and artistic metaphors that highlight the affective, relational and ontological dimensions of learners' framings of reality, their theories of social and ecological change, and their attachments to these ways of knowing and being (see also Steelman et al. 2018). This can involve, for example, inviting learners to encounter a physical, intellectual or emotional limit of possibility and to understand how they engage with that limit (rather than seeking immediately to transgress it using familiar resources). This can be supported by offering an analytical framework of 'affective dispositions of engagement' which they can use to interpret individual and collective responses to this experience. Identifying different dispositions-as experienced in the body as well as the mindnot only enables us to distinguish between 'defensiveness', 'discomfort' or 'discernment', but to consider the practical implications of each disposition and become aware of others, including 'disarming' the dispositions that subordinate nonhegemonic modes of experience and knowledge (Gesturing Towards Decolonial Futures 2018b). Another pedagogical tool being developed within the collective, also using metaphor as a way to combine rational and affective meaning, is an open-source 'zine' that supports an activity called 'The house modernity built'. On the one side, it presents an image of a crumbling house and a brief 'analysis of how modernity affects our reasoning, our sense of self and reality, our desires, and our perceived entitlements, impairing our capacity to feel, to hope, to relate, and to be and imagine differently' (Gesturing Towards Decolonial Futures 2018c). On the other side is a framework for future-making practice that outlines dimensions of ecological, cognitive, affective, relational and economic forms of justice ('EarthCARE') and facilitates reflection on how each may be hindered or advanced by different ways of knowing and being. This tool aims to help learners go 'beyond the search for universal models and problem-solving approaches' to global and ecological justice 'towards preparing people to work together with and through the complexities, uncertainties, paradoxes, and complicities that characterize efforts to address unprecedented global challenges collaboratively today' (EarthCARE 2018). It offers a framework of epistemic and ontological diversity with which learners can learn to recognize, respect and challenge intersecting forms of epistemic and ontological impoverishment in their own practices in order to enlarge possibilities for being and becoming otherwise.

Such pedagogies do not aim to develop individuals' 'competencies for sustainability' (UNESCO 2018); make existing institutions, practices and ways of life more sustainable; or " "fix" the structural mechanisms that produce inequalities' today (Andreotti et al. 2015, 2018). Their counter-intuitive (within hegemonic educational systems) function is to invite learners to 're-orient logos/logic in order to make room for the ineffable' forces that shape the very ways it is possible for us to experience reality and imagine and live towards the future (Andreotti 2016, 2018), as well as to invite them to sit with the intellectual, affective, relational and practical difficulties of actually doing this. In other words, learners are invited not only to learn about harmful structures, social relations and subjectivities that have brought us to our present conjuncture, but also to unlearn our investments in these structures, relations and subjectivities. Encounters with different knowledge systems and social practices are therefore not meant as a strategy for acquiring and consuming new knowledges, but rather for denaturalizing the structures of knowing, being and wanting that treat knowledge as a site of acquisition and accumulation, and for facing the affective responses that emerge when those patterns are challenged.

This approach can be characterized as neither making 'futures for the present' (coherent plans or visions to guide future action) nor making ' "presents for the future' (producing knowledge and action that we are confident can influence developmental trajectories in responsible ways) (Knappe et al. 2018) but as 'gesturing' towards both activities in the present absence of adequate conditions of possibility for either. The 
GTDF collective uses the term 'gesture' to distinguish its practices from approaches to education for global ecological justice that are based on 'demands, manifestos or prescriptions' for the future. As forms of embodied, non-verbal or more-thanverbal communication, gestures have a special relationship to possibility as they invite participation in shared meaningmaking without demanding it or determining its form. They are indicators of 'intention rather than full-blown... arguments' (Naranch 2009), and they play a special role in both expressing 'troublesome knowledge'-Meyer and Land (2003) term for that "which is "alien", or counter-intuitive, or even intellectually absurd at face value'-and that which 'cannot or should not be expresses in words' or what 'one wishes to keep out of sound's reach' (Rodríguez 2014). Making 'gestures' towards alternative, non-capitalist futures in the form of tentative theory-making and experimental educational practice is therefore one way of opening spaces for emerging possibilities that would otherwise be incorporated into existing frameworks of knowledge and systems of social organization, or closed down as 'unrealistic'. When creative, a gesture can therefore be 'a resource for resistance to homogenization, a way to place pressure on the routines demanded by technical and technological standardization' even before the routines themselves and the ontological assumptions upon which they are based can be openly questioned or significantly transformed (Noland 2008). Because as 'a way of articulating political action gesture highlights intensions, process, and practice over objectives and certainty' (Rodríguez 2014), it is a meaningful future-oriented movement in conditions in which we cannot be certain that our ways of making futures are not colonized by the limitations of our present ways of knowing and being in the world, including the 'blind spots' that are created by our desires for ready-made alternatives that can be applied from other contexts. As Julian Carter notes, the word 'gesture' derives from a Latin word (gesturus) that means 'I am about to carry' or bear (Carter 2013). 'To gesture', therefore, 'is to embody one's intention, and may entail assuming a certain open-ended responsibility for what one carries' (Carter 2013). Educators who are developing pedagogies to address the root causes of modern social and ecological suffering and to enable the imagination of social futures which are not based on logics of separation, hierarchy, supremacy and the instrumentalization of life describe their work as gesture because, while they do not believe they can responsibly create full-blown 'presents for the future' from within present (modern/colonial) realities, they seek to open up possibilities for being otherwise in their orientations towards both present and future.

Acknowledgements I thank Sharon Stein, Vanessa Andreotti, and the editors and reviewers of this article for their critical and caring readings and their contributions to its improvement.

Open Access This article is distributed under the terms of the Creative Commons Attribution 4.0 International License (http://creativeco mmons.org/licenses/by/4.0/), which permits unrestricted use, distribution, and reproduction in any medium, provided you give appropriate credit to the original author(s) and the source, provide a link to the Creative Commons license, and indicate if changes were made.

\section{References}

Ahenakew C, Andreotti V, Cooper G, Hireme H (2014) Beyond epistemic provincialism: de-provincializing indigenous resistance. AlterNative Int J Indig Peoples 10(3):216-231

Amsler S (2009) Embracing the politics of ambiguity: towards a normative theory of 'sustainability'. Capital Nat Soc 20(2):111-125

Andreotti V (2016) (re)imagining education as an uncoercive rearrangement of desire. Other Educ J Educ Altern 5(1):79-88

Andreotti V (2018) Multi-layered selves: colonialism, decolonization and counter-intuitive learning spaces. ArtsEverywhere, 12 October. http://artseverywhere.ca/2016/10/12/multi-layeredselves/. Accessed 28 Nov 2018

Andreotti V, Stein S, Ahenakew C, Hunt D (2015) Mapping interpretations of decolonization in the context of higher education. Decolonization Indig Educ Soc 4(1):21-40

Andreotti V, Stein S, Sutherland A, Pashby K, Suša R, Amsler S with the Gesturing Towards Decolonial Futures Collective (2018) Mobilising different conversations about global justice in education: toward alternative futures in uncertain times. Policy and Practice: A Development Education Review, 26. https://www. developmenteducationreview.com/issue/issue-26/mobilising -different-conversations-about-global-justice-education-towar d-alternative. Accessed 28 Nov 2018

Barad K (2015) Transmaterialities: trans*/matter/realities and queer political imaginings. J Gay Lesbian Stud 21(2-3):387-422

Barraza RS (2005) Interview with Raymundo Sánchez Barraza: a university without shoes. InMotion Magazine, 3 September. http://www.inmotionmagazine.com/global/rsb_int_eng.html. Accessed 28 Nov 2018

Carter J (2013) Embracing transition: dancing in the folds of time. In: Stryker S, Aizura A (eds) The transgender studies reader, vol 2. Routledge, London

Dorling D (2010) Injustice: why social inequality persists. Policy Press, Bristol

EarthCARE Network (2018). https://blogs.ubc.ca/earthcare/netwo rk/. Accessed 28 Nov 2018

Ecoversities Alliance (2018) Website. http://ecoversities.org

Enlivened Learning (2018) What can learning become? http://enliv enedlearning.com/the-project/. Accessed 28 Nov 2018

Freire P (2016) Pedagogy of the heart. Bloomsbury, London

Gesturing Towards Decolonial Futures (2018a) Gestures... https:// decolonialfutures.net/. Accessed 28 Nov 2018

Gesturing Towards Decolonial Futures (2018b) Affective dispositions of engagement. CartographicExperiment. https://decol onialfutures.net/portfolio/affective-dispositions-of-engagement 1. Accessed 28 Nov 2018

Gesturing Towards Decolonial Futures (2018c) The house modernity built. Cartographic Experiment. https://decolonialfutures.net/ portfolio/mini-zine-house-mycelium/. Accessed 28 Nov 2018

Giraldo I (2016) Coloniality at work: decolonial critique and the postfeminist regime. Fem Theory 17(2):157-173

Green J (2015) The environmental curriculum: opportunities for environmental education across the National Curriculum for England, Early Years Stage \& Primary. National Association for Environmental Education UK. http://naee.org.uk/wp-conte nt/uploads/2015/06/NAEE_The_Environmental_Curriculum .pdf. Accessed 28 Nov 2018 
Jefferess D (2012) The 'Me to We' social enterprise: global education as lifestyle brand. Crit Lit Theor Pract 6(1):18-30

Knappe H, Holfelder A, Löw Beer D, Nanz P (2018) The politics of making and un-making (sustainable) futures. Sustain Sci 13(2):273-274

Lugones M (2010) Toward a decolonial feminism. Hypatia 25(4):742-759

Marcuse H (1992) Ecology and the critique of society. Capital Nat Soc 3(3):29-48

Meyer JHF, Land R (2003) Threshold concepts and troublesome knowledge: linkages to ways of thinking and practising within the disciplines. In: Rust C (ed) Improving student learning-ten years on. OCSLD, Oxford

Naranch L (2009) Smart, funny, and romantic? Femininity and feminist gestures in chick flicks. In: Goren L (ed) You've come a long way, baby: women, politics, and popular culture. University Press of Kentucky, Kentucky

Noland C (2008) Introduction. In: Noland C, Ness SA (eds) Migrations of gesture. University of Minnesota Press, Minnesota

Povinelli E (2011) Routes/worlds. E-flux, 27. https://www.e-flux.com/ journal/27/67991/routes-worlds/. Accessed 28 Nov 2018

Povinelli E (2012) The will to be otherwise/the effort of endurance. South Atl Q 111(3):453-475

Rodríguez JM (2014) Sexual futures, queer gestures, and other Latina longings. New York University Press, New York

Santos BdS (2016) Epistemologies of the South and the future. From Eur South 1(1):17-29

Santos BdS (2017) Beyond abyssal thinking: from global lines to ecologies of knowledges. Eurozine, 20 June. https://www.eurozine.com/ beyond-abyssal-thinking/. Accessed 28 Nov 2018

Santos BdS, Arriscado Nunes J, Meneses MP (2007) Opening up the canon of knowledge and recognition of Difference. In: Santos B (ed) Another knowledge is possible: beyond northern epistemologies. Verso, London

Shahjahan R, Wagner A (2018) Unpacking ontological security: a decolonial readingof scholarly impact. Educ Philos Theory. https ://doi.org/10.1080/00131857.2018.1454308
Shahjahan R, Blanco Ramirez G, Andreotti V (2017) Attempting to imagine the unimaginable: a decolonial reading of global university rankings. Comp Educ Rev 61(S1):S51-S73

Shotwell A (2016) Against purity: living ethically in compromised times. University of Minnesota Press, Minnesota

Steelman T, Andrews E, Baines S, Bharadwaj L, Bjornson E, Bradford L, Cardinal K, Carriere G, Fresque-Baxter J, Jardine T, MacColl I, Macmillan S, Maren J, Reed M, Rose I, Shmon K, Shantz S, Staples K, Strickert G, Voyageur M (2018) Identifying transformational space for transdisciplinarity: using art to access the hidden third. Sustain Sci. https://doi.org/10.1007/s11625-018-0644-4

Stein S, Hunt D, Suša R, de Oliveira Andreotti V (2017) The educational challenge of unravelling the fantasies of ontological security. Diaspora Indig Minor Educ 11(2):69-79

Teamey K, Mandel U (2018) Emergent learning in solidarity. Arts Everywhere. http://artseverywhere.ca/roundtables/pedagogy-other wise-responses/. Accessed 28 Nov 2018

UNESCO (2005) Emerging and re-emerging learning communities: old wisdoms and new initiatives from around the world. UNESCO, Paris

UNESCO Education for Sustainable Development Learning Objectives (2018). http://unesdoc.unesco.org/images/0024/002474/24744 4e.pdf. Accessed 28 Nov 2018

Walton E (2018) Decolonising (through) inclusive education? Educ Res Soc Change 7:31-45

Weber H (2017) Politics of leaving no one behind: contesting the 2030 Sustainable Development Goals agenda. Globalizations 14(3):388-411

Williams L (2013) Deepening ecological relationality through critical onto-epistemological inquiry: where transformative learning meets sustainable science. J Transform Educ 11(2):95-113

Publisher's Note Springer Nature remains neutral with regard to jurisdictional claims in published maps and institutional affiliations. 